\title{
Article \\ A Cross-Sectional Analysis of the Association between Domestic Cooking Energy Source Type and Respiratory Infections among Children Aged under Five Years: Evidence from Demographic and Household Surveys in 37 Low-Middle Income Countries
}

\author{
Zubaidah Al-Janabi ${ }^{\dagger}$, Katherine E. Woolley ${ }^{\dagger}\left(\mathbb{D}\right.$, G. Neil Thomas $^{*}$ and Suzanne E. Bartington
}

check for updates

Citation: Al-Janabi, Z.; Woolley, K.E.; Thomas, G.N.; Bartington, S.E. A Cross-Sectional Analysis of the Association between Domestic Cooking Energy Source Type and Respiratory Infections among Children Aged under Five Years: Evidence from Demographic and Household Surveys in 37 Low-Middle Income Countries. Int. J. Environ. Res. Public Health 2021, 18, 8516. https:// doi.org/10.3390/ijerph18168516

Academic Editor: Paul B. Tchounwou

Received: 16 July 2021

Accepted: 8 August 2021

Published: 12 August 2021

Publisher's Note: MDPI stays neutral with regard to jurisdictional claims in published maps and institutional affiliations.

Copyright: (C) 2021 by the authors Licensee MDPI, Basel, Switzerland. This article is an open access article distributed under the terms and conditions of the Creative Commons Attribution (CC BY) license (https:/ / creativecommons.org/licenses/by/ $4.0 /)$.
Institute of Applied Health Research, University of Birmingham, Edgbaston, Birmingham B15 2TT, UK; ZXA945@alumni.bham.ac.uk (Z.A.-J.); KEW863@student.bham.ac.uk (K.E.W.); s.bartington@bham.ac.uk (S.E.B.)

* Correspondence: g.n.thomas@bham.ac.uk or gneilthomas@gmail.com; Tel.: +44-1214148696

† Joint first author.

Abstract: Background: In low- and middle-income countries (LMICs), household air pollution as a result of using solid biomass for cooking, lighting and heating (HAP) is associated with respiratory infections, accounting for approximately 4 million early deaths each year worldwide. The majority of deaths are among children under five years. This population-based cross-sectional study investigates the association between solid biomass usage and risk of acute respiratory infections (ARI) and acute lower respiratory infections (ALRI) in 37 LMICs within Africa, Americas, Southeast Asia, European, Eastern Mediterranean and Western Pacific regions. Materials and methods: Using population-based data obtained from Demographic and Health surveys (2010-2018), domestic cooking energy sources were classified solid biomass (wood, charcoal/dung, agricultural crop) and cleaner energy sources (e.g., Liquid Petroleum Gas (LPG), electricity, biogas and natural gas). Composite measures of ARI (shortness of breath, cough) and ALRI (shortness of breath, cough and fever) were composed using maternally reported respiratory symptoms over the two-week period prior to the interview. Multivariable logistic regression was used to identify the association between biomass fuel usage with ARI and ALRI, accounting for relevant individual, household and situational confounders, including stratification by context (urban/rural). Results: After adjustment, in the pooled analysis, children residing in solid biomass cooking households had an observed increased adjusted odds ratio of ARI (AOR: 1.17; 95\% CI: 1.09-1.25) and ALRI (AOR: 1.16; 95\% CI 1.07-1.25) compared to cleaner energy sources. In stratified analyses, a comparable association was observed in urban areas (ARI: 1.16 [1.06-1.28]; ALRI: 1.14 [1.02-1.27]), but only significant for ARI among those living in rural areas (ARI: 1.14 [1.03-1.26]). Conclusion: Switching domestic cooking energy sources from solid biomass to cleaner alternatives would achieve a respiratory health benefit in children under five years worldwide. High quality mixed-methods research is required to improve acceptability and sustained uptake of clean cooking energy source interventions in LMIC settings.

Keywords: biomass cooking; household air pollution; acute respiratory infection; low and middleincome countries

\section{Introduction}

In low- and middle-income countries (LMICs), household air pollution (HAP) is associated with acute respiratory infections (ARI) and acute lower respiratory infection (ALRI) as a result of using solid biomass for cooking, lighting and heating [1,2]. Solid biomass fuels, including coal, charcoal, crop waste and dung, are used by more than three billion people worldwide primarily in LMIC settings due to widespread availability and lower cost [3]. However, these fuels produce harmful levels of pollutants, including 
particulate matter $(\mathrm{PM})$, carbon monoxide $(\mathrm{CO})$, sulphur dioxide $\left(\mathrm{SO}_{2}\right)$ and nitrogen oxides $\left(\mathrm{NO}_{\mathrm{x}}\right)$. Inequalities in the level of exposure are present between different household members, with women and children experiencing the highest exposure levels [4], due to women performing the majority of domestic duties including the preparing and cooking of food [5] typically accompanied by young children during cooking periods [6,7]. This high exposure in children under five years increases their risk of ARI [8], asthmas [9], stunting [10], otitis media [11], poor neurodevelopment [12] and mortality [10], with over four million deaths associated with HAP exposure each year [13].

Interventions to reduce HAP exposure, including Liquefied Petroleum Gas (LPG), Biogas, Improved cookstove (ICS), biomass pellets and behaviour change (e.g., removing children from the cooking area) [14], have indicated some health-related benefits throughout the life-course in some countries [15]. Implementation of such interventions faces multiple challenges in LMIC settings, due to lack of financial resources, awareness and accessibility $[15,16]$. Imposing changes to adopt cleaner cooking energy sources is challenging, with high start-up costs and need for ongoing investment in changing household behaviours in LMICs [17]. However, HAP interventions present a number of longer-term benefits including economic savings, despite the upfront costs [17]; environmental benefits such as a reduction in deforestation [18]; reduced opportunity costs [19]; and wider social benefits through gender equality, female empowerment and additional time for education [19].

Previous research identified a strong association between the use solid biomass cooking fuel and reduced risk of respiratory infections in India [20,21], Pakistan [22] and Africa [23], especially among households with less educated parents [24]. However, to the best of our knowledge, there is a paucity of evidence of ARI risk between solid biomass and cleaner cooking energy sources on a global scale taking into consideration both ARI and ALRI. Utilising data obtained from Demographic and Health Survey (DHS) for 37 LMICs worldwide, this paper aims to investigate differences in the association between solid biomass and cleaner cooking energy sources with risk of ARI and ALRI among children aged under five years old.

\section{Materials and Methods}

\subsection{Setting and Study Design}

Data were obtained from the nationally representative population-based demographic and health survey, funded by U.S. Agency for International Development and other participating countries [16], collected repeated survey every four years from over 90 countries. Each survey has a multi-stage stratified sampling strategy that provides high-quality information on family planning, fertility, maternal and child health, nutrition and other living condition aspects [25].

For this cross-sectional study, relevant data for children under five years old were extracted from the most recent DHS surveys conducted between 2010 to 2018 for countries with available data resulting in the selection of 37 completed surveys (Figure 1).

\subsection{Ethical Approval and Authorisation}

ICF Institutional Review Board (IRB) and individual country government ethical approval board, provided ethical approval for survey data collection. All data are anonymised and made publicly available on the DHS website [26]. Data access authorisation was provided by DHS [27]. 


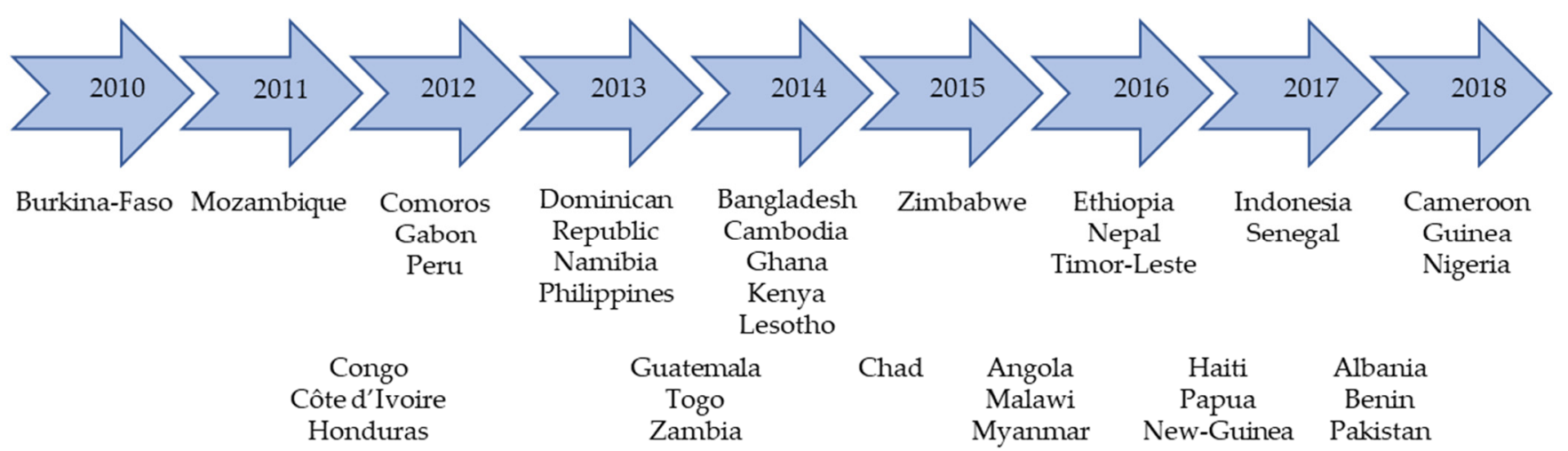

Figure 1. Countries and DHS questionnaire dates included in this study.

\subsection{Data Variables}

\subsubsection{Outcome/Dependent Variables}

ARI and ALRI are composite outcome measures derived from maternal report of respiratory symptoms (cough, short rapid breath or difficulty breathing, and fever) in children under five years occurring in the two-week period prior to the survey contact. ARI was defined as the presence of cough and short rapid breaths [28], while ALRI defined as the presence when cough, short rapid breath and fever [28]; each were modelled as a binary (yes, no) outcome variable.

\subsubsection{Exposure/Independent Variables}

Household cooking energy sources were categorised into cleaner (electricity, LPG, natural gas, biogas) and biomass (kerosene, coal/lignite, charcoal, wood, straw/shrubs/grass, agricultural crop, animal dung) fuel types [29].

\subsubsection{Child, Maternal and Paternal Characteristics}

Children's characteristics comprised (a) child age $(<1,1,2,3$, 4 years old), (b) child sex (female, male), (c) mode of delivery (vaginal, caesarean) and (d) breastfeeding status (ever breastfed, never breastfed). Maternal characteristics comprised (a) maternal age (15-24, 25-35, 36-49 in years), (b) highest educational level (none, primary, secondary/higher) and (c) highest education level of husband (none, primary, secondary/higher).

\subsubsection{Household and Contextual Characteristics}

Household characteristics considered in the analysis were (a) indoor household smoking (yes, no), (b) number of household members as a proxy for household crowding $(\leq 6$, $>6$ ), (c) household cooking location (inside, outdoors) and (d) wealth index (lowest, low, middle, high, highest). The wealth index measure used according to DHS socio-economic five categories, using wealth indicator variables collected within the household survey. Every collected household indicator variable gets assigned a factor score through principal component analysis and the resulting scores are then standardised in a normal distribution using a mean of zero and standard deviation of one. These standardised scores are then used to generate and define the wealth index categories as lowest, low, middle, high and highest [30]. Contextual characteristics included (a) rural or urban residence (urban, rural) and (b) region of residence.

\subsection{Data Analysis}

$\mathrm{R}$ studio [31] was used for data management, manipulation and analysis. A summary of descriptive statistics was derived using number of cases (n) and percentages (\%) as all our variables were either categorical or binary. Multivariable logistic regression analysis was conducted using univariate stepwise selection with the survey package in $\mathrm{R}$ studio and with odds ratios (OR), 95\% confidence interval (95\% CI) and $\mathrm{p}$ values reported. Confounding factors included in the final adjusted model included child sex and age, mode of delivery, 
maternal age and level of education, wealth index, cooking location, number of household members, region and urban or rural residence. As some countries had low cell counts or entirely missing values for breastfeeding status, household smoking status and husband's level of education, exploratory analysis for these factors was undertaken only among those countries where these variables were available. An additional sub-analysis stratified by rural and urban residence was also undertaken. Multicollinearity was checked by the variance inflation factor (VIF), using Car package in R studio [32].

\section{Results}

\subsection{Descriptive Analysis}

In the pooled dataset of 353,802 children living in 37 countries, $79.6 \%$ lived in solid fuel cooking households and $20.4 \%$ resided in cleaner cooking energy source households (Figures 2 and 3). Overall, there were 32,438 (10.8\%) cases of ARI and 19,426 (6.5\%) cases of ALRI occurring in the two weeks prior to interview (Table 1). Proportions of clean cooking energy sources use varied across the included countries with $88.5 \%$ using cleaner cooking energy sources in Dominican Republic compared to $1.4 \%$ in Guinea (Figure 2). Haiti had the highest period prevalence of ALRI (15.5\%) and ARI (28.9\%), compared to the lowest in Albania (ARI: $1.7 \%$ and ALRI: 5.5\%; Figure 4).

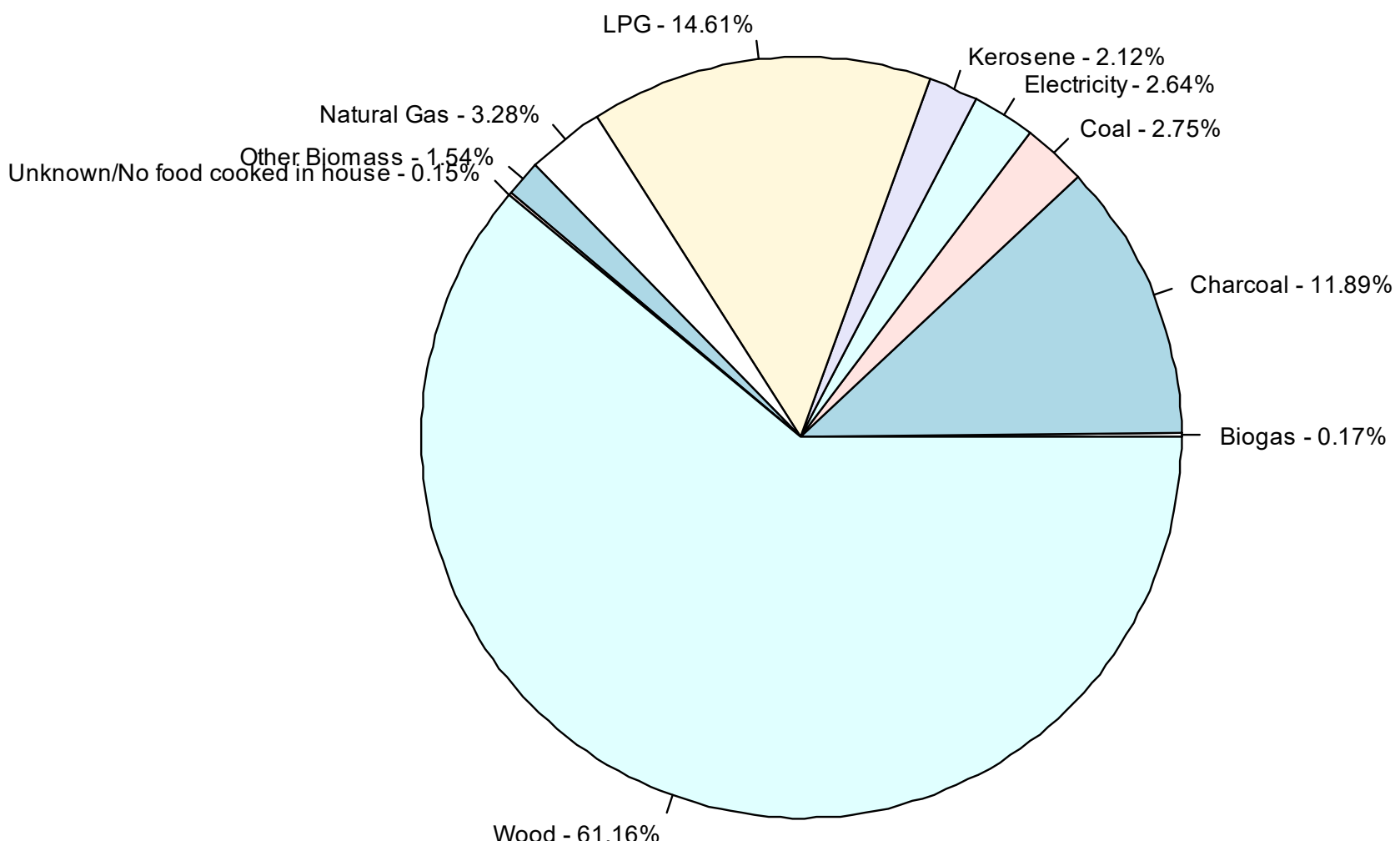

Figure 2. Proportion of children residing in households using different cooking energy source types within the pooled dataset. 
Dominican Republic 2013, N = 3618

Gabon 2012, N = 5122 Indonesia 2017, N = 17,019 Albania 2017-18, N = 2561

Peru 2012, $N=8426$ Angola 2015-16, $N=13,356$ Pakistan 2017-18, N = 10,494 Hondaura 2011-12, N = 10,174

Namibia 2013, $N=4804$

Lesotho 2014, N = 3112

Philipines 2013, N = 6982 Gutemala 2014-15, N = 12,504

Zimbabwe 2015, N = 6418 Nepal 2016, $\mathrm{N}=5060$

Ghana 2014, N = 5695

Sengal 2017, $N=11,280$ Myanamar 2015-16, N = 4286

Cambodia 2014, N = 7253

Cameroon 2018, N = 10,061

Congo 2011-12, $N=8170$

Côte d'Ivoire 2011-12, N = 7492

Nigeria 2018, $\mathrm{N}=34,193$

Kenya 2014, N = 19,564

Zambia 2013-14, N = 13,383

Papua New Guinea, N = 9761

Togo 2013-14, N = 6706

Ethiopia 2016, $\mathrm{N}=11,023$

Haiti 2016-17, N = 6303

Benin 2017-18, N = 13,643

Comoros 2012, N = 3235

Chad 2014, N = 18,635

Burkina Faso 2010, N = 15,375

Mozambique 2011, $N=11,704$

Malawi 2015-16, $\mathrm{N}=17,395$

Guinea 2018, N = 7885

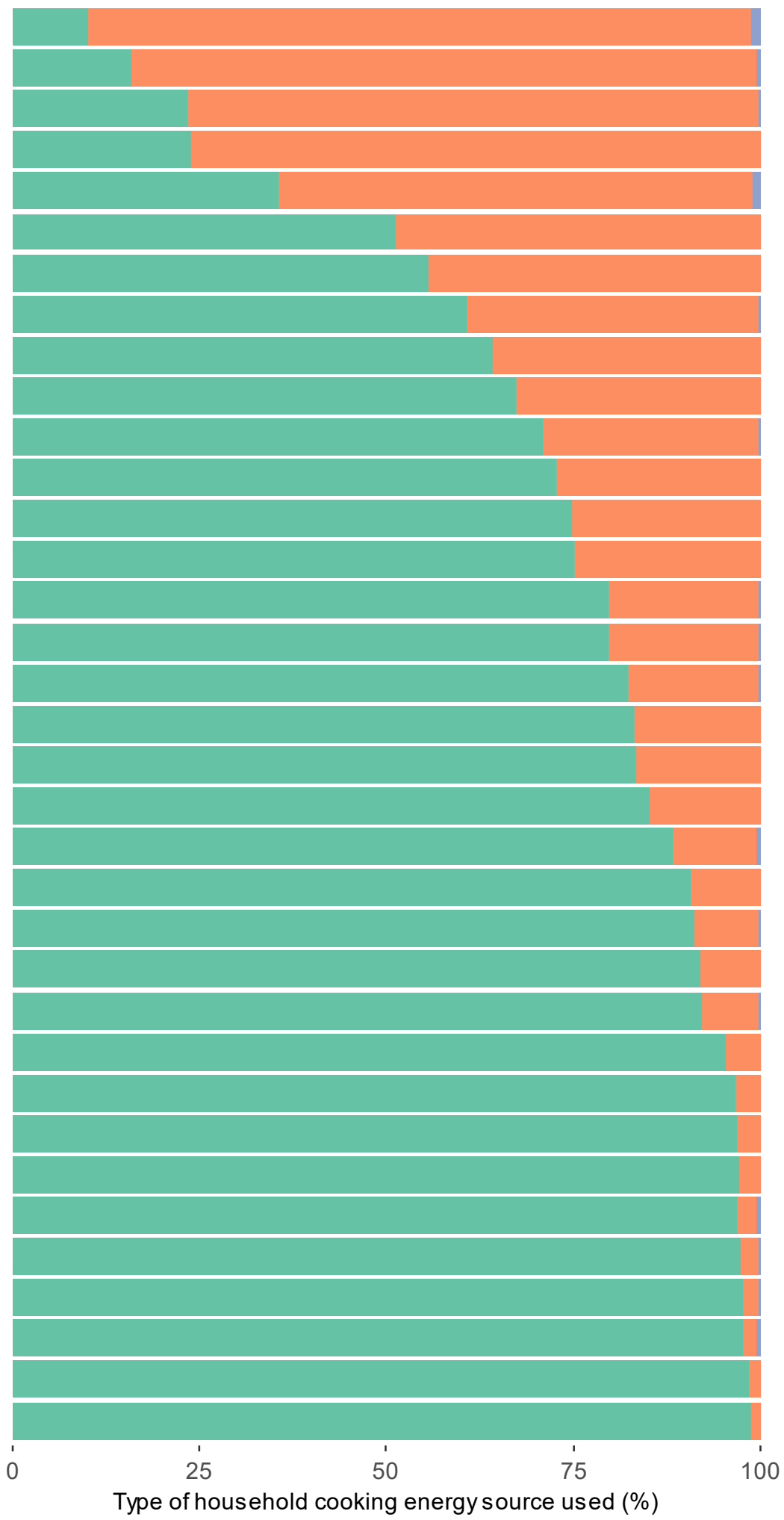

\section{Biomass Cleaner Unknown/No food cooked in house}

Figure 3. Proportion of children residing in households using cleaner and biomass cooking energy sources by country. 


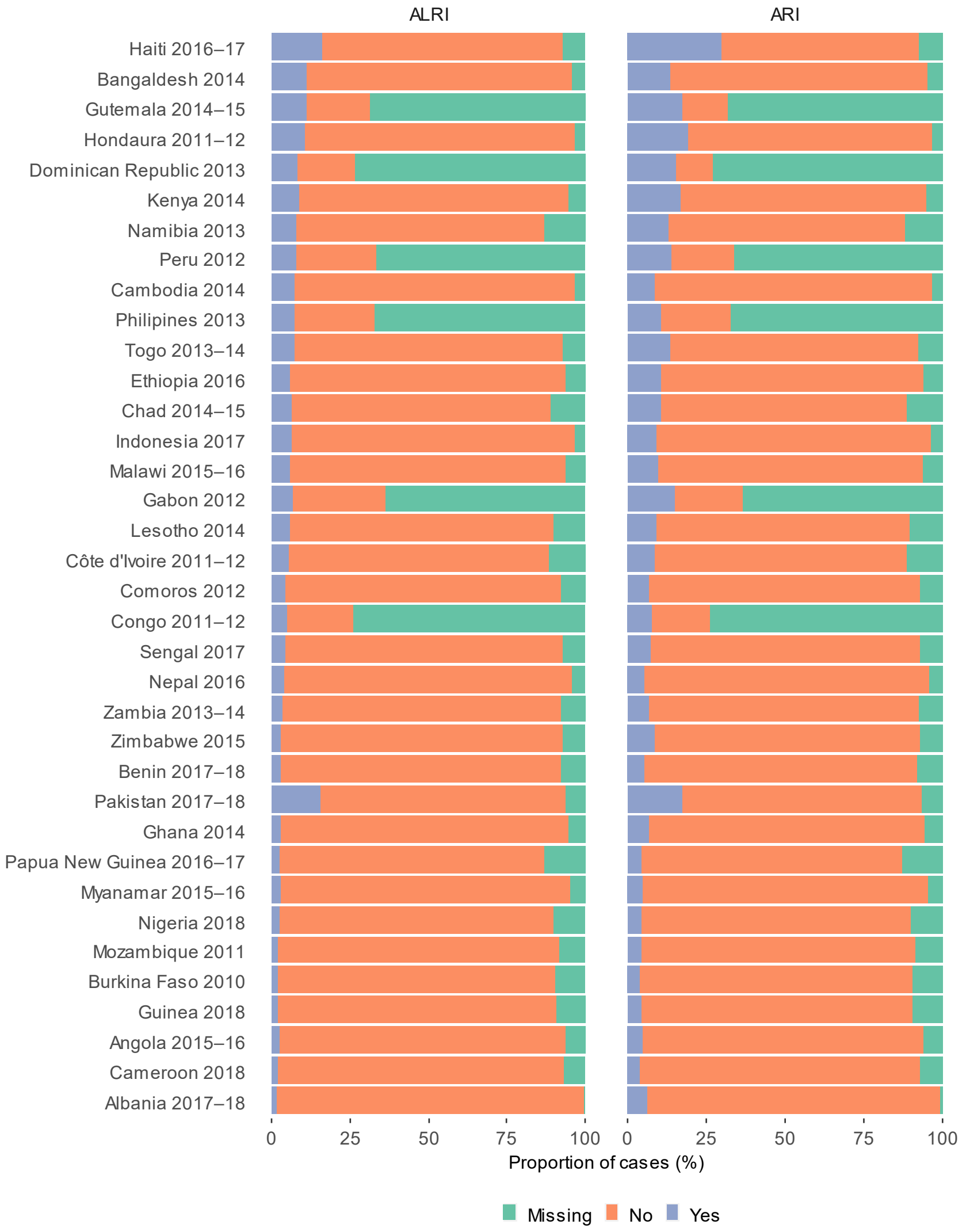

Figure 4. Proportion of ARI and ALRI cases in children under five by country. 
Table 1. Descriptive statistics for ARI and ALRI within the pooled dataset $(\mathrm{N}=353,802)$.

\begin{tabular}{|c|c|c|c|c|c|c|}
\hline \multirow[b]{2}{*}{$\begin{array}{l}\text { Explanatory } \\
\text { Variables }\end{array}$} & \multicolumn{3}{|c|}{$\begin{array}{c}\text { ARI } \\
N=299,118\end{array}$} & \multicolumn{3}{|c|}{$\begin{array}{c}\text { ALRI } \\
\mathrm{N}=298,841\end{array}$} \\
\hline & $\begin{array}{c}\text { Yes } \\
\mathrm{N}=32,438(10.8 \%)\end{array}$ & $\begin{array}{c}\text { No } \\
\mathrm{N}=266,679(89.2 \%)\end{array}$ & $p$ Value & $\begin{array}{c}\text { Yes } \\
\mathrm{N}=19,426(6.5 \%)\end{array}$ & $\begin{array}{c}\text { No } \\
\mathrm{N}=\mathbf{2 7 9 , 4 1 5}(93.5 \%)\end{array}$ & $p$ Value \\
\hline \multicolumn{2}{|l|}{ Cooking energy source } & & 0.012 & & & 0.081 \\
\hline Clean & $6547(20.2 \%)$ & $47,187(17.7 \%)$ & & $3770(19.4 \%)$ & $49,921(17.9 \%)$ & \\
\hline Biomass & $25,824(79.8 \%)$ & $219,015(82.3 \%)$ & & $15,615(80.6 \%)$ & $228,992(82.1 \%)$ & \\
\hline Missing & 67 & 477 & & 41 & 502 & \\
\hline \multicolumn{2}{|l|}{ Child age (years) } & & $<0.001$ & & & $<0.001$ \\
\hline$<1$ & $7572(23.3 \%)$ & $55,614(20.9 \%)$ & & $4441(22.9 \%)$ & $58,720(21.0 \%)$ & \\
\hline 1 & $7873(24.3 \%)$ & $53,320(20.0 \%)$ & & $5102(26.3 \%)$ & $56,039(20.1 \%)$ & \\
\hline 2 & $6476(20.0 \%)$ & $51,828(19.4 \%)$ & & $3913(20.1 \%)$ & $54,349(19.5 \%)$ & \\
\hline 3 & $5682(17.5 \%)$ & $53,057(19.9 \%)$ & & $3266(16.8 \%)$ & $55,397(19.8 \%)$ & \\
\hline 4 & $4835(14.9 \%)$ & $52,860(19.8 \%)$ & & $2703(13.9 \%)$ & $54,910(19.7 \%)$ & \\
\hline \multicolumn{2}{|l|}{ Sex of child } & & $<0.001$ & & & $<0.001$ \\
\hline Male & $16,811(51.8 \%)$ & $134,922(50.6 \%)$ & & $10,099(52.0 \%)$ & $141,489(50.6 \%)$ & \\
\hline Female & $15,627(48.2 \%)$ & $131,757(49.4 \%)$ & & $9327(48.0 \%)$ & $137,926(49.4 \%)$ & \\
\hline \multicolumn{2}{|l|}{ Mode of delivery } & & $<0.001$ & & & $<0.001$ \\
\hline Vaginal & $28,437(88.9 \%)$ & $244,809(93.0 \%)$ & & $17,000(89.2 \%)$ & $255,981(92.8 \%)$ & \\
\hline Caesarean & $3557(11.1 \%)$ & $18,436(7.0 \%)$ & & $2065(10.8 \%)$ & 19,917 (7.2\%) & \\
\hline Missing & 444 & 3435 & & 362 & 3517 & \\
\hline \multicolumn{2}{|l|}{ Breastfeeding status } & & $<0.001$ & & & $<0.001$ \\
\hline Ever breast fed & $25,602(96.4 \%)$ & $219,737(96.3 \%)$ & & $15,390(96.1 \%)$ & $229,736(96.3 \%)$ & \\
\hline Never breast fed & $953(3.6 \%)$ & $8461(3.7 \%)$ & & $620(3.9 \%)$ & $8782(3.7 \%)$ & \\
\hline Missing & 5883 & 38,481 & & 3416 & 40,896 & \\
\hline \multicolumn{2}{|l|}{ Maternal age (Years) } & & $<0.001$ & & & $<0.001$ \\
\hline $15-24$ & $10,545(32.5 \%)$ & $75,517(28.3 \%)$ & & $6260(32.2 \%)$ & $79,685(28.5 \%)$ & \\
\hline $25-35$ & $16,650(51.3 \%)$ & $143,162(53.7 \%)$ & & $10,014(51.5 \%)$ & $149,672(53.6 \%)$ & \\
\hline $36-49$ & $5244(16.2 \%)$ & $48,001(18.0 \%)$ & & $3152(16.2 \%)$ & $50,057(17.9 \%)$ & \\
\hline \multicolumn{2}{|c|}{ Maternal level of education } & & $<0.001$ & & & $<0.001$ \\
\hline No education & $7686(23.7 \%)$ & $92,024(34.5 \%)$ & & $4751(24.5 \%)$ & $94,882(34.0 \%)$ & \\
\hline Primary & $13,026(40.2 \%)$ & $88,356(33.1 \%)$ & & $7825(40.3 \%)$ & $93,467(33.5 \%)$ & \\
\hline Secondary or Higher & $11,726(36.1 \%)$ & $86,272(32.4 \%)$ & & $6851(35.3 \%)$ & $91,038(32.6 \%)$ & \\
\hline Missing & 0 & 29 & & 0 & 29 & \\
\hline \multicolumn{2}{|l|}{ Household wealth index } & & $<0.001$ & & & $<0.001$ \\
\hline Lowest & $7902(24.4 \%)$ & $60,168(22.6 \%)$ & & $4977(25.6 \%)$ & $63,041(22.6 \%)$ & \\
\hline Low & $7335(22.6 \%)$ & $57,061(21.4 \%)$ & & $4446(22.9 \%)$ & $59,886(21.4 \%)$ & \\
\hline Middle & $6744(20.8 \%)$ & $53,640(20.1 \%)$ & & $4029(20.7 \%)$ & $56,295(20.1 \%)$ & \\
\hline High & $5850(18.0 \%)$ & $50,981(19.1 \%)$ & & $3391(17.5 \%)$ & $53,379(19.1 \%)$ & \\
\hline Highest & $4607(14.2 \%)$ & $44,829(16.8 \%)$ & & $2582(13.3 \%)$ & $46,814(16.8 \%)$ & \\
\hline \multicolumn{2}{|l|}{ Place of residence } & & $<0.001$ & & & $<0.001$ \\
\hline Urban & $11,387(35.1 \%)$ & $90,829(34.1 \%)$ & & $6565(33.8 \%)$ & $95,551(34.2 \%)$ & \\
\hline Rural & $21,051(64.9 \%)$ & $175,850(65.9 \%)$ & & $12,861(66.2 \%)$ & $183,864(65.8 \%)$ & \\
\hline \multicolumn{7}{|l|}{ Household smoking } \\
\hline No & $18,370(73.7 \%)$ & $182,328(74.0 \%)$ & & $10,514(71.8 \%)$ & $189,978(74.1 \%)$ & \\
\hline Yes & $6561(26.3 \%)$ & $63,968(26.0 \%)$ & & $4135(28.2 \%)$ & $66,340(25.9 \%)$ & \\
\hline Missing & 7507 & 20,384 & & 4777 & 23,098 & \\
\hline \multicolumn{2}{|c|}{ Number of households members } & & $<0.001$ & & & $<0.001$ \\
\hline$\leq 6$ & $19,835(61.2 \%)$ & $155,110(58.2 \%)$ & & $11,834(60.9 \%)$ & $162,905(58.3 \%)$ & \\
\hline$\geq 6$ & $12,592(38.8 \%)$ & $111,369(41.8 \%)$ & & $7586(39.1 \%)$ & $116,305(41.7 \%)$ & \\
\hline Missing & 11 & 201 & & 6 & 205 & \\
\hline \multicolumn{2}{|l|}{ Cooking location } & & $<0.001$ & & & $<0.001$ \\
\hline Indoors & $24,520(75.8 \%)$ & $188,269(70.8 \%)$ & & $14,657(75.7 \%)$ & $197,942(71.0 \%)$ & \\
\hline Outdoors & $7826(24.2 \%)$ & $77,651(29.2 \%)$ & & $4702(24.3 \%)$ & $80,690(29.0 \%)$ & \\
\hline Missing & 92 & 759 & & 67 & 783 & \\
\hline \multicolumn{2}{|l|}{ Paternal level of education } & & $<0.001$ & & & $<0.001$ \\
\hline No education & $5692(20.4 \%)$ & $71,767(30.7 \%)$ & & $3505(20.8 \%)$ & $73,897(30.2 \%)$ & \\
\hline Primary & $10,201(36.6 \%)$ & $69,809(29.9 \%)$ & & $6226(37.0 \%)$ & $73,718(30.1 \%)$ & \\
\hline Secondary or Higher & $11,946(42.9 \%)$ & $92,192(39.4 \%)$ & & $7110(42.2 \%)$ & $96,957(39.6 \%)$ & \\
\hline Missing & 4599 & 32,911 & & 2585 & 34,844 & \\
\hline
\end{tabular}




\subsection{Risk of ARI and ALRI in Children under Five}

After adjusting for individual and household confounding factors, solid biomass cooking was observed to independently increase the adjusted odds ratio of ARI compared to cleaner cooking energy sources in Papua New Guinea (AOR: 4.91; 95\% CI: 2.08-11.50), Cameroon (AOR: 1.92; 95\% CI: 1.14-3.23) and Peru (AOR:1.47; 95\% CI: 1.05-2.05) (Figure 5). In the pooled analysis, there was an observed increase the adjusted odds ratio of ARI (AOR: 1.17; 95\% CI: 1.09-1.25) with solid biomass cooking compared to cleaner cooking energy sources (Table 2). However, for ALRI an increase in the adjusted odds ratio with biomass cooking was observed in Kenya (AOR: 5.00; 95\% CI: 1.10-22.60), Papua New Guinea (AOR: 4.28; 95\% CI: 1.58-11.60), Cameroon (AOR: 3.15; 95\% CI: 1.09-9.05), Zambia (AOR: $2.69 ; 95 \%$ CI: 1.13-6.39) and Honduras (AOR: 1.52; 95\% CI: 1.13-2.04), compared to cleaner cooking energy sources (Figure 6). A similar adjusted odds ratio was observed in the pooled analysis, with a greater risk of ALRI (AOR: 1.16; 95\% CI: 1.07-1.25) associated with living in biomass cooking compared to cleaner cooking energy source households.

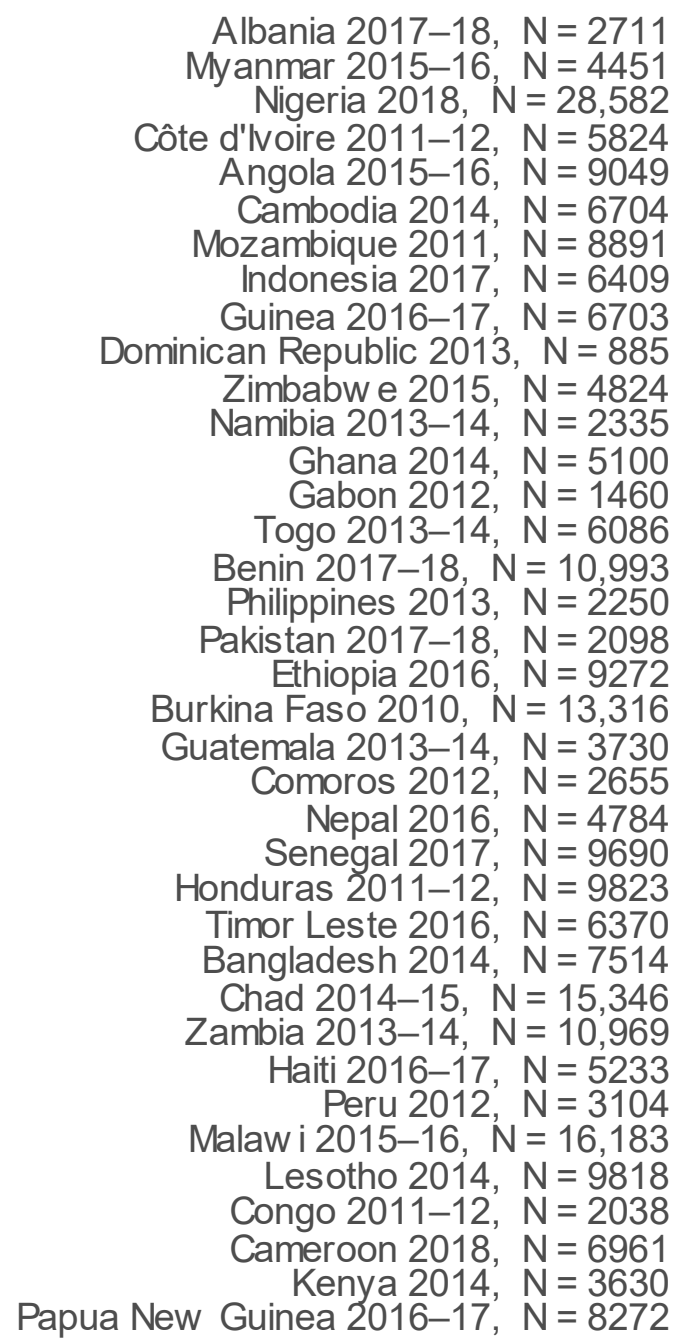

Pooled summary, $\mathrm{N}=298,379$

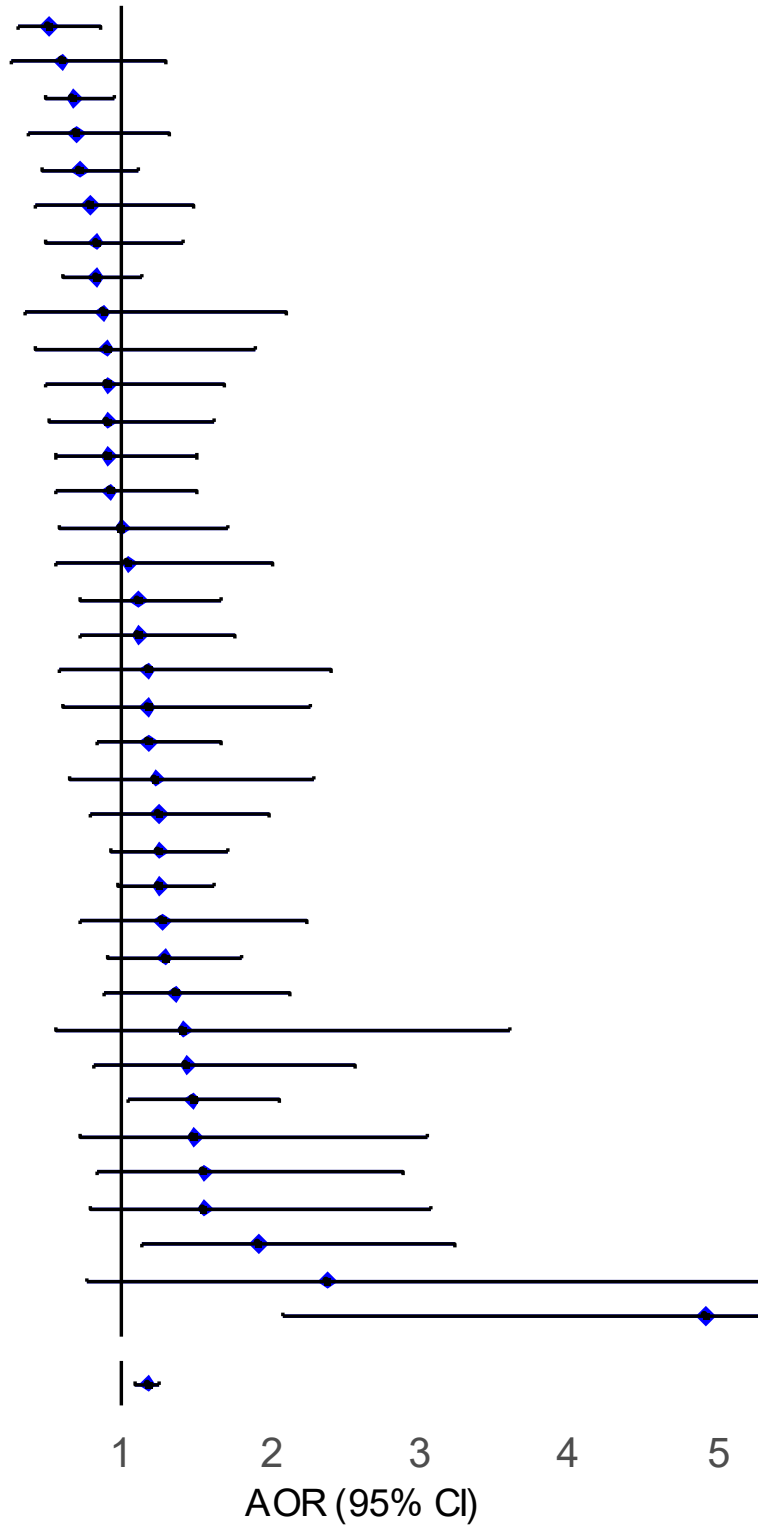

AOR $(95 \% \mathrm{Cl})$

Figure 5. Forest plot for the adjusted odds ratio (AOR) for ARI in children aged under five years with biomass cooking compared to cleaner cooking for all countries. 
Table 2. Adjusted odds ratio (AOR) with 95\% CI for the association of ARI and ALRI in children aged under five years with biomass cooking compared to cleaner cooking.

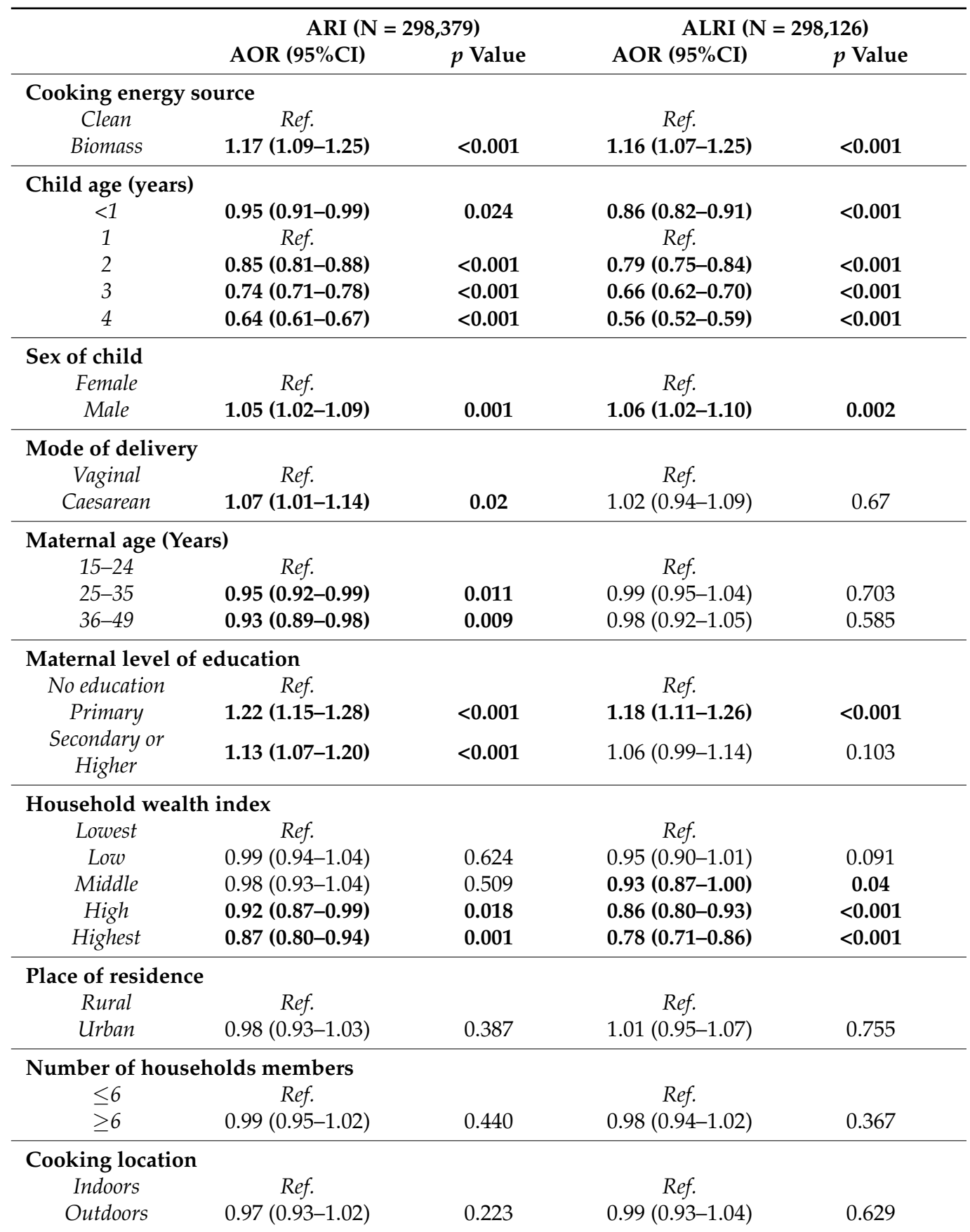

Abbreviation: $\mathrm{N}=$ number of observations, $\mathrm{AOR}=$ Adjusted Odds Ratio, $95 \% \mathrm{CI}=95 \%$ confidence interval. Ref. $=$ Reference group. The bold is for the results to illustrate significant results below $p=0.05$. Unadjusted results: Appendix A: Table A1.

Within the stratified sub-analysis, similar associations were observed (Table 3). Among children living in urban areas only there was an increased risk of ARI (AOR: 1.16; 95\% CI: 1.06-1.28) and ALRI (AOR: 1.14; 95\% CI: 1.02-1.27) in biomass cooking compared to cleaner cooking households. An association was observed for ARI (AOR: 1.14; 95\%CI: 1.03-1.26) in rural areas only, but not for ALRI (AOR: 1.13; 95\% CI: 1.00-1.27) (Table 2). 


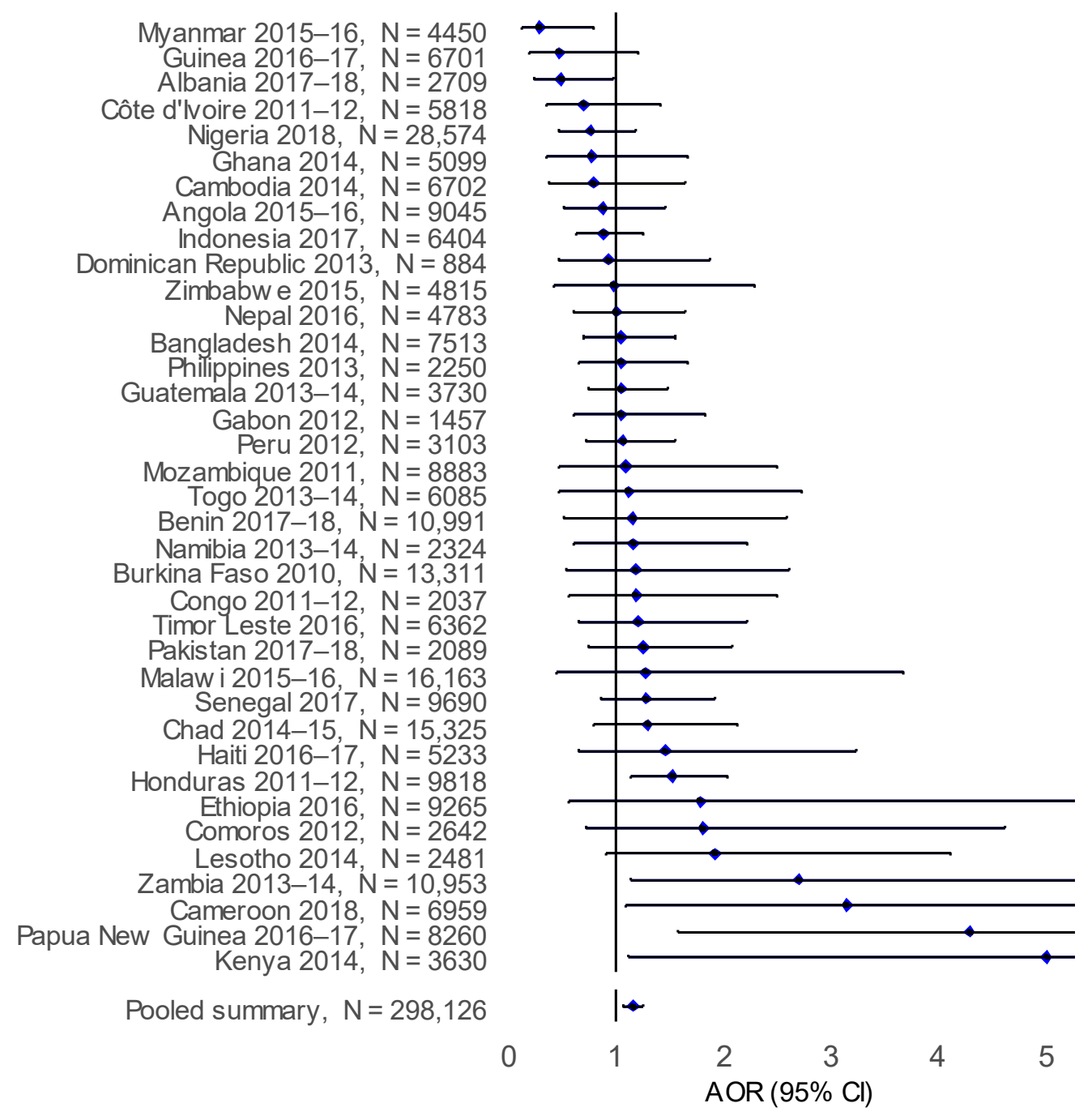

Figure 6. Forest plot for the adjusted odds ratio (AOR) for ALRI in children aged under five years with biomass cooking compared to cleaner cooking for all countries.

Table 3. Adjusted odds ratio (AOR) with $95 \%$ CI for the association of ARI and ALRI in children aged under five years with biomass cooking compared to cleaner cooking for rural and urban areas.

\begin{tabular}{|c|c|c|c|c|}
\hline \multirow{2}{*}{ Analysis (N) } & \multicolumn{2}{|c|}{ ARI } & \multicolumn{2}{|c|}{ ALRI } \\
\hline & AOR $(95 \% C I)$ & $p$ Value & AOR $(95 \% \mathrm{CI})$ & $p$ Value \\
\hline \multicolumn{5}{|c|}{ Sub-analysis } \\
\hline Urban areas only $(n=101,444)$ & $1.16(1.06-1.28)$ & 0.001 & $1.14(1.02-1.27)$ & 0.018 \\
\hline Rural areas only $(n=196,682)$ & $1.14(1.03-1.26)$ & 0.010 & $1.13(1.00-1.27)$ & 0.051 \\
\hline
\end{tabular}

Abbreviation: $\mathrm{N}=$ number of observations, $\mathrm{AOR}=$ Adjusted Odds Ratio, 95\% CI $=95 \%$ confidence interval The bold is for the results to illustrate significant results below $p=0.05 . n=$ Number of observations within the sub-analysis.

\section{Discussion}

Solid biomass domestic fuels are used as a main source of energy in many countries worldwide, primarily due to the lack of access to clean energy alternatives. Our large-scale $(\mathrm{N}=353,802)$ cross-sectional study conducted across 37 LMICs between 2010 and 2018 indicates that cooking with cleaner energy sources could reduce ARI and ALRI by $17 \%$ and $16 \%$, respectively, among children under five years, compared to traditional solid biomass cooking energy source usage. We observe the benefits of clean cooking energy source alternatives to be even more pronounced among urban LMIC subpopulations, with important implications for targeted cooking energy source transition policies. 
Although there is a clear benefit of cleaner cooking of improving childhood respiratory outcomes, there exists a lack of national and international policy attention to facilitating sustained access and uptake of cleaner cooking energy sources [33]. Not only have we identified substantial between-country variation in ARI risk associated with biomass cooking, but there is also widespread variation in provision of clean cooking energy source alternatives and cooking practices. In our analyses, we include household wealth to adjust for the influence of socio-economic factors operating at a household level; however, it is recognised that the macroeconomic context will influence cooking energy source accessibility and choice based upon market prices [34,35]. In addition, our analysis explored impacts of health and behavioural factors (e.g., household smoking, breastfeeding and husband's level of education) within countries with relevant available data, identifying that these potential confounders have little influence on reducing ARI risk $(13 \%, 14 \%$ and $13 \%$, respectively) in children under five (Appendix A: Table A2). The complex relationship between cooking energy source choice and external situational and contextual factors is well recognised (such as traditional practices, local economic situation and cooking energy source availability) [36] and any individual country level policy should attempt to identify and capitalise upon relevant situational factors which could affect sustained clean cooking energy source uptake in the longer term.

Notably, within our study are the observed differences in the risk of ARI between rural and urban areas, with marginally higher risk in children residing urban areas, which is a well-recognised phenomenon in other settings [2], due to different situational (e.g., source of pollutant emissions, healthcare access and nutritional status) [37], and behavioural characteristics (e.g., cooking location and time spent indoors) [38]. As most children worldwide spend most of their time in indoor settings [39,40], particularly within this age group, given children under five years are typically not yet attending school, we did not attempt to capture any measures of outdoor (ambient) pollution such as household proximity to roads, industrial sites and neighbouring households cooking energy source, which may mitigate the benefits of cleaner cooking energy source use [41,42]. However, it is well recognised that the relationship between indoor and outdoor air quality is complex, influenced by factors such as housing characteristics, housing density, cooking location and ventilation mechanisms dominate emissions sources and quantities of exposure [43]. Nevertheless, as children are known to typically spend a substantial proportion of time in close proximity to the cooking location in these contexts [39,40]; therefore, this is likely to present as the major emissions source and dominant exposure microenvironment in this age group.

Clean and biomass cooking have been well defined by the WHO, however, there is internal variation within these categories, with studies indicating that there are potential respiratory health benefits associated with each step up the fuel ladder [2,44], for example, by substitution of solid biomass fuels with kerosene. The WHO previously categorised kerosene as a cleaner energy source, even though it is more polluting than LPG; some analyses have previously used this categorisation [45], limiting potential comparability. However, when exploring categorising kerosene as a cleaner energy source (Appendix A: Table A3), within the combined dataset, there was little observable effect on the over ARI risk (ARI: 20\%, ALRI 19\%), which could be due to the lower number of kerosene users globally. Cleaner energy source use remains infrequent in many countries, limiting the inclusion of some countries within the analysis and these countries should encourage policies to improve cleaner energy source usage. Despite this limitation 37 LMICs and 353,802 children were included in our analyses supporting published country or regional level literature on the potential respiratory health benefit of cleaner cooking energy sources [23,46-49].

This study fully supports previous recommendations made by Odo et al. 2021 [50] to improve the DHS questionnaire, to add further questions regarding cooking and heating practices (e.g., stove and multiple fuel stacking) to allow for a more comprehensive assessment; which was an inherent limitation within this study. In addition, we highlight the need to document the prevailing weather/season at time of interview within the DHS 
survey, as climatic conditions are known to influence ARI risk [23], cooking location [51,52] fuel type and dryness of wood, enabling greater insight into the current situation at the time of interview. Having an improved undertaking of the contemporary situation at the time of interview would reduce some of the uncertainties around the self-reported measures collected. Although collection of self-reported respiratory symptoms lack a definitive clinical diagnosis and biological specificity [53], uncertainty is reduced by obtaining maternally reported in the two week prior to the interview, allowing for diagnosis in a large proportion of surveyed children. In addition, ARI risk and proportion of cleaner energy source usage could have changed over time, with the included surveys being undertaken between 2010 and 2018; however, all surveys were undertaken with the same methodology. Despite the limitations described, the DHS data provides an opportunity to analysis data which has a large population-based samples from multiple settings, an excellent response rate and national coverage and the use of uniform surveys, with robust fieldworker training and coordination $[50,54,55]$.

\section{Conclusions}

Replacing solid biomass cooking with cleaner energy source alternatives will likely reduce the incidence of ALRI and ARI in children under five years, in resource poor settings worldwide. Any further structural, fiscal and behavioural cleaner cooking energy source interventions should consider the country level cultural and situational factors associated sustained clean energy source uptake. Urban settings should be considered for prioritised targeting of fuel transition policies to deliver maximum child health benefits. Future mixedmethods research should consider implementation, adaptation and adverse or unintended events of cleaner cooking energy source transition, to have sustained uptake for maximum public health benefit.

Author Contributions: Conceptualization, Z.A.-J., K.E.W., G.N.T. and S.E.B.; methodology, Z.A.-J. and K.E.W.; validation, K.E.W.; formal analysis, Z.A.-J.; resources, K.E.W.; data curation, Z.A.-J. and K.E.W.; writing - original draft preparation, Z.A.-J., K.E.W. and S.E.B.; writing—review and editing, K.E.W., S.E.B. and G.N.T.; visualization, Z.A.-J.; supervision, K.E.W., G.N.T. and S.E.B. All authors have read and agreed to the published version of the manuscript.

Funding: K.E.W. is funded by a University of Birmingham Global Challenges PhD Scholarship.

Institutional Review Board Statement: Not applicable, as secondary data analysis. Information of ethical approval for the primary data collection can be found at https:/ / dhsprogram.com/ (accessed on 28 February 2021).

Informed Consent Statement: Informed consent was obtained from all subjects involved in the study. Informed consent for the primary data collection can be found at https:// dhsprogram.com/ (accessed on 28 February 2021).

Data Availability Statement: Data is freely and publicly available from https:/ dhsprogram.com/ data/ (accessed on 28 February 2021).

Acknowledgments: We are grateful for access and use of the DHS data.

Conflicts of Interest: The authors declare no conflict of interest. 


\section{Appendix A}

Table A1. Unadjusted odds ratio (OR) with $95 \%$ CI for the association of ARI and ALRI in children aged under five years with biomass cooking compared to cleaner cooking.

\begin{tabular}{|c|c|c|c|c|}
\hline & \multicolumn{2}{|c|}{ ARI } & \multicolumn{2}{|c|}{ ALRI } \\
\hline & OR $(95 \% \mathrm{CI})$ & $p$ Value & OR $(95 \% C I)$ & $p$ Value \\
\hline \multicolumn{5}{|c|}{ Cooking energy source (Kerosene categorised as biomass energy source) } \\
\hline Clean & Ref. & & Ref. & \\
\hline Biomass & $0.85(0.80-0.90)$ & $<0.001$ & $0.90(0.85-0.96)$ & 0.001 \\
\hline \multicolumn{5}{|c|}{ Cooking energy source (Kerosene categorised as clean energy source) } \\
\hline Clean & Ref. & & Ref. & \\
\hline Biomass & $0.89(0.84-0.94)$ & $<0.001$ & $0.95(0.89-1.00)$ & 0.067 \\
\hline \multicolumn{5}{|l|}{ Child age (years) } \\
\hline$<1$ & $0.92(0.88-0.96)$ & $<0.001$ & $0.83(0.79-0.87)$ & $<0.001$ \\
\hline 1 & Ref. & & Ref. & \\
\hline 2 & $0.85(0.81-0.88)$ & $<0.001$ & $0.79(0.75-0.83)$ & $<0.001$ \\
\hline 3 & $0.73(0.69-0.76)$ & $<0.001$ & $0.65(0.61-0.68)$ & $<0.001$ \\
\hline 4 & $0.62(0.59-0.65)$ & $<0.001$ & $0.54(0.51-0.57)$ & $<0.001$ \\
\hline \multicolumn{5}{|l|}{ Sex of child } \\
\hline Female & Ref. & & Ref. & \\
\hline Male & $1.05(1.02-1.08)$ & 0.001 & $1.06(1.02-1.09)$ & 0.003 \\
\hline \multicolumn{5}{|l|}{ Mode of delivery } \\
\hline Vaginal & Ref. & & Ref. & \\
\hline Caesarean & $1.66(1.57-1.76)$ & $<0.001$ & $1.56(1.46-1.67)$ & $<0.001$ \\
\hline \multicolumn{5}{|l|}{ Breastfeeding status } \\
\hline Ever breast fed & Ref. & & Ref. & \\
\hline Never breast fed & $0.97(0.87-1.07)$ & 0.528 & $1.56(1.46-1.67)$ & $<0.001$ \\
\hline \multicolumn{5}{|l|}{ Maternal age (Years) } \\
\hline $15-24$ & Ref. & & Ref. & \\
\hline $25-35$ & $0.83(0.80-0.86)$ & $<0.001$ & $1.67(1.58-1.77)$ & $<0.001$ \\
\hline $36-49$ & $0.78(0.75-0.82)$ & $<0.001$ & $1.50(1.41-1.60)$ & $<0.001$ \\
\hline \multicolumn{5}{|c|}{ Maternal level of education } \\
\hline No education & Ref. & & Ref. & \\
\hline Primary & $1.77(1.68-1.85)$ & $<0.001$ & $1.67(1.58-1.77)$ & $<0.001$ \\
\hline Secondary or Higher & $1.63(1.54-1.72)$ & $<0.001$ & $1.50(1.41-1.60)$ & $<0.001$ \\
\hline \multicolumn{5}{|c|}{ Household wealth index } \\
\hline Lowest & Ref. & & Ref. & \\
\hline Low & $0.98(0.93-1.03)$ & 0.403 & $0.94(0.89-1.00)$ & 0.044 \\
\hline Middle & $0.96(0.90-1.01)$ & 0.131 & $0.91(0.85-0.97)$ & 0.003 \\
\hline High & $0.87(0.82-0.93)$ & $<0.00$ & $0.80(0.75-0.86)$ & $<0.001$ \\
\hline Highest & $0.78(0.73-0.84)$ & $<0.001$ & $0.70(0.65-0.75)$ & $<0.001$ \\
\hline \multicolumn{5}{|l|}{ Place of residence } \\
\hline Rural & Ref. & & Ref. & \\
\hline Urban & $1.05(1.00-1.10)$ & 0.065 & $0.98(0.93-1.04)$ & 0.526 \\
\hline \multicolumn{5}{|l|}{ Household smoking } \\
\hline No & Ref. & & Ref. & \\
\hline Yes & $1.03(0.99-1.08)$ & 0.132 & $1.15(1.09-1.21)$ & $<0.001$ \\
\hline \multicolumn{5}{|c|}{ Number of households members } \\
\hline$\leq 6$ & Ref. & & Ref. & \\
\hline$\geq 6$ & $0.88(0.85-0.92)$ & $<0.001$ & $0.90(0.86-0.94)$ & $<0.001$ \\
\hline \multicolumn{5}{|l|}{ Cooking location } \\
\hline Indoors & Ref. & & Ref. & \\
\hline Outdoors & $0.77(0.74-0.81)$ & $<0.001$ & $0.79(0.75-0.83)$ & $<0.001$ \\
\hline \multicolumn{5}{|c|}{ Paternal level of education } \\
\hline No education & Ref. & & Ref. & \\
\hline Primary & $1.84(1.74-1.95$ & $<0.001$ & $1.78(1.67-1.90)$ & $<0.001$ \\
\hline Secondary or Higher & $1.63(1.54-1.73)$ & $<0.001$ & $1.55(1.45-1.65)$ & $<0.001$ \\
\hline
\end{tabular}

Abbreviations: OR = Unadjusted Odds Ratio, 95\% CI = 95\% confidence interval. Ref. = Reference group. The bold is for the results to illustrate significant results below $p=0.05$. 
Table A2. Adjusted odds ratio (AOR) with 95\% CI of the exploratory analyses for the association of ARI and ALRI in children aged under five years with biomass cooking compared to cleaner cooking.

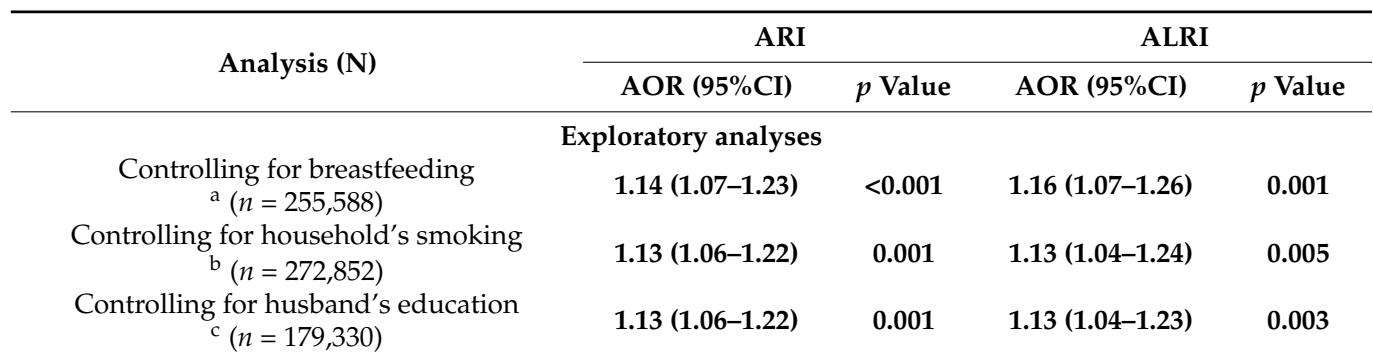

Abbreviation: $\mathrm{N}=$ number of observations, AOR = Adjusted Odds Ratio, 95\% CI = 95\% confidence interval. (a) Excluded: Albania 2017-2018, Angola 2015-2016, Burkina Faso 2010, Mozambique 2011, Myanmar 2015-2016, Nepal 2016, Senegal 2017, Zambia 2013-2014, Papua New Guinea 2016-2017, Bangladesh 2014, Dominican Republic 2013 and Peru 2012; (b) Excluded: Guatemala 2014-2015, Philippines 2013, Kenya 2014, Bangladesh 2014, Dominican Republic 2013 and Peru 2012; (c) Excluded: Malawi 2015-2016, Kenya 2014 and Papua New Guinea 2016-2017. The bold is for the results to illustrate significant results below $p=0.05$.

Table A3. Adjusted odds ratio (AOR) with 95\% CI for the association of ARI and ALRI in children aged under five years with biomass cooking compared to cleaner cooking, where kerosene is classified as a cleaner energy source.

\begin{tabular}{|c|c|c|c|c|}
\hline & $\begin{array}{r}\text { AR } \\
\text { AOR }(95 \% \mathrm{CI})\end{array}$ & $p$ Value & AOR $(95 \%$ ALI & $p$ Value \\
\hline & \multicolumn{2}{|c|}{$\mathrm{N}=298,379$} & \multicolumn{2}{|c|}{$\mathrm{N}=298,126$} \\
\hline $\begin{array}{c}\text { Cooking energy source } \\
\text { Clean } \\
\text { Biomass }\end{array}$ & $\begin{array}{c}\text { Ref. } \\
1.20(1.12-1.27)\end{array}$ & $<0.001$ & $\begin{array}{c}\text { Ref. } \\
1.19(\mathbf{1 . 1 0 - 1 . 2 8 )})\end{array}$ & $<0.001$ \\
\hline $\begin{array}{r}\text { Child age (years) } \\
<1 \\
1 \\
2 \\
3 \\
4\end{array}$ & $\begin{array}{c}0.95(0.91-0.99) \\
\text { Ref. } \\
0.84(0.81-0.88) \\
0.74(0.71-0.78) \\
0.64(0.61-0.67)\end{array}$ & $\begin{array}{l}0.024 \\
<0.001 \\
<0.001 \\
<0.001\end{array}$ & $\begin{array}{c}0.86(0.81-0.91) \\
\text { Ref. } \\
0.79(0.75-0.84) \\
0.66(0.62-0.70) \\
0.56(0.52-0.59)\end{array}$ & $\begin{array}{l}<0.001 \\
<0.001 \\
<0.001 \\
<0.001\end{array}$ \\
\hline Sex of child & $\begin{array}{c}\text { Ref. } \\
0.74(0.71-0.78)\end{array}$ & $<0.001$ & $\begin{array}{c}\text { Ref. } \\
0.66(0.62-0.70)\end{array}$ & $<0.001$ \\
\hline $\begin{array}{r}\text { Mode of delivery } \\
\text { Vaginal } \\
\text { Caesarean }\end{array}$ & $\begin{array}{c}\text { Ref. } \\
1.08(1.01-1.14)\end{array}$ & 0.018 & $\begin{array}{c}\text { Ref. } \\
1.02(0.95-1.09)\end{array}$ & 0.646 \\
\hline $\begin{array}{r}\text { Maternal age (Years) } \\
15-24 \\
25-35 \\
36-49\end{array}$ & $\begin{array}{l}0.95(0.92-0.99) \\
0.93(0.89-0.98)\end{array}$ & $\begin{array}{l}0.011 \\
0.009\end{array}$ & $\begin{array}{l}0.99(0.95-1.04) \\
0.98(0.92-1.05)\end{array}$ & $\begin{array}{c}0.719 \\
0.59\end{array}$ \\
\hline $\begin{array}{c}\text { Maternal level of education } \\
\text { No education } \\
\text { Primary } \\
\text { Secondary or Higher }\end{array}$ & $\begin{array}{c}\text { Ref. } \\
1.22(1.16-1.29) \\
1.14(1.07-1.21)\end{array}$ & $\begin{array}{l}<0.001 \\
<0.001\end{array}$ & $\begin{array}{c}\text { Ref. } \\
\mathbf{1 . 1 8}(\mathbf{1 . 1 1 - 1 . 2 6 )} \\
1.07(0.99-1.15)\end{array}$ & $\begin{array}{c}<0.001 \\
0.088\end{array}$ \\
\hline $\begin{array}{c}\text { Household wealth index } \\
\text { Lowest } \\
\text { Low } \\
\text { Middle } \\
\text { High } \\
\text { Highest }\end{array}$ & $\begin{array}{c}\text { Ref. } \\
0.99(0.94-1.04) \\
0.98(0.93-1.04) \\
\mathbf{0 . 9 3}(\mathbf{0 . 8 7 - 0 . 9 9 )} \\
\mathbf{0 . 8 8}(\mathbf{0 . 8 1 - 0 . 9 5 )}\end{array}$ & $\begin{array}{l}0.657 \\
0.577 \\
\mathbf{0 . 0 3 1} \\
\mathbf{0 . 0 0 1}\end{array}$ & $\begin{array}{c}\text { Ref. } \\
0.95(0.90-1.01) \\
\mathbf{0 . 9 4}(\mathbf{0 . 8 8 - 1 . 0 0 )} \\
\mathbf{0 . 8 7}(\mathbf{0 . 8 0 - 0 . 9 4 )} \\
\mathbf{0 . 7 9}(\mathbf{0 . 7 2 - 0 . 8 7 )}\end{array}$ & $\begin{array}{c}0.101 \\
0.05 \\
<0.001 \\
<0.001\end{array}$ \\
\hline $\begin{array}{r}\text { Place of residence } \\
\text { Rural } \\
\text { Urban }\end{array}$ & $\begin{array}{c}\text { Ref. } \\
0.99(0.94-1.04)\end{array}$ & 0.617 & $\begin{array}{c}\text { Ref. } \\
1.02(0.96-1.08)\end{array}$ & 0.537 \\
\hline $\begin{array}{c}\text { Number of households members } \\
\leq 6 \\
\geq 6\end{array}$ & $0.98(0.95-1.02)$ & 0.341 & $0.98(0.93-1.02)$ & 0.295 \\
\hline $\begin{array}{r}\text { Cooking location } \\
\text { Indoors } \\
\text { Outdoors }\end{array}$ & $\begin{array}{l}\text { Ref. } \\
0.97(0.93-1.01)\end{array}$ & 0.165 & $\begin{array}{c}\text { Ref. } \\
0.98(0.93-1.04)\end{array}$ & 0.528 \\
\hline & Sub-analy & & & \\
\hline $\begin{array}{l}\text { Urban areas only }(n=101,444) \\
\text { Rural areas only }(n=196,682)\end{array}$ & $\begin{array}{l}1.18(1.08-1.29) \\
1.17(1.06-1.29)\end{array}$ & $\begin{array}{c}<0.001 \\
0.002\end{array}$ & $\begin{array}{l}1.17(1.05-1.30) \\
1.15(1.02-1.29)\end{array}$ & $\begin{array}{l}0.003 \\
0.024\end{array}$ \\
\hline
\end{tabular}

Abbreviation: $\mathrm{N}=$ number of observations, AOR = Adjusted Odds ratio, 95\% CI = 95\% confidence interval Ref. $=$ Reference group. ${ }^{*}$ Results for Sub-analysis are biomass cooking compared to cleaner cooking. $n=$ Number of observations within the sub-analysis. The bold is for the results to illustrate significant results below $p=0.05$. 


\section{References}

1. Sanbata, H.; Asfaw, A.; Kumie, A. Association of biomass fuel use with acute respiratory infections among under- five children in a slum urban of Addis Ababa, Ethiopia. BMC Public Health 2014, 14, 1122. [CrossRef]

2. Woolley, K.E.; Bagambe, T.; Singh, A.; Avis, W.R.; Kabera, T.; Weldetinsae, A.; Mariga, S.T.; Kirenga, B.; Pope, F.D.; Neil Thomas, G.; et al. Investigating the association between wood and charcoal domestic cooking, respiratory symptoms and acute respiratory infections among children aged under 5 years in uganda: A cross-sectional analysis of the 2016 demographic and health survey. Int. J. Environ. Res. Public Health 2020, 17, 3974. [CrossRef]

3. International Energy Agency. Share of Population Relying on Different Cooking Fuels in Selected Countries, 2015-Charts-Data \& Statistics-IEA. Available online: https:/ / www.iea.org/data-and-statistics/charts/share-of-population-relying-on-differentcooking-fuels-in-selected-countries-2015 (accessed on 22 September 2020).

4. Okello, G.; Devereux, G.; Semple, S. Women and girls in resource poor countries experience much greater exposure to household air pollutants than men: Results from Uganda and Ethiopia. Environ. Int. 2018, 119, 429-437. [CrossRef] [PubMed]

5. Admasie, A.; Kumie, A.; Worku, A. Children under five from houses of unclean fuel sources and poorly ventilated houses have higher odds of suffering from acute respiratory infection in Wolaita-Sodo, Southern Ethiopia: A case-control study. J. Environ. Public Health 2018, 2018, 9320603. [CrossRef]

6. Smith, K.R.; Samet, J.M.; Romieu, I.; Bruce, N. Indoor air pollution in developing countries and acute lower respiratory infections in children. Thorax 2000, 55, 518-532. [CrossRef] [PubMed]

7. Toman, M.; Bluffstone, R. Challenges in Assessing the Costs of Household Cooking Energy in Lower-Income Countries; World Bank Group Policy Research Working Paper; World Bank Group: Washington, DC, USA, 2017; Volume 25. [CrossRef]

8. Taylor, E.T.; Nakai, S. The levels of toxic air pollutants in kitchens with traditional stoves in rural Sierra Leone. J. Environ. Prot. 2012, 3, 1353-1363. [CrossRef]

9. Romieu, I.; Samet, J.M.; Smith, K.R.; Bruce, N. Outdoor air pollution and acute respiratory infections among children in developing countries. J. Occup. Environ. Med. 2002, 44, 640-649. [CrossRef]

10. Bruce, N.; Pope, D.; Rehfuess, E.; Balakrishnan, K.; Adair-Rohani, H.; Dora, C. WHO indoor air quality guidelines on household fuel combustion: Strategy implications of new evidence on interventions and exposure-risk functions. Atmos. Environ. 2015, 106, 451-457. [CrossRef]

11. Da Costa, J.L.; Navarro, A.; Neves, J.B.; Martin, M. Household wood and charcoal smoke increases risk of otitis media in childhood in Maputo. Int. J. Epidemiol. 2004, 33, 573-578. [CrossRef]

12. World Health Organization (WHO). Air Pollution and Child Health. Available online: https://www.who.int/news/item/29-102018-more-than-90-of-the-worlds-children-breathe-toxic-air-every-day (accessed on 2 March 2021).

13. Bickton, F.M.; Ndeketa, L.; Sibande, G.T.; Nkeramahame, J.; Payesa, C.; Milanzi, E.B. Household air pollution and under-five mortality in sub-Saharan Africa: An analysis of 14 demographic and health surveys. Environ. Health Prev. Med. 2020, 25, 67. [CrossRef] [PubMed]

14. Venkata Ramana, P.; Michael, T.; Sumi, M.; Kammila, S. The State of the Global Clean and Improved Cooking Sector; Energy Sector Management Assistance Program Technical Paper No. 007/15; World Bank: Washington, DC, USA, 2015.

15. Woolley, K.E.; Dickinson-Craig, E.; Bartington, S.E.; Oludotun, T.; Kirenga, B.; Mariga, S.T.; Kabera, T.; Coombe, A.; Pope, F.D.; Singh, A.; et al. Effectiveness of interventions to reduce household air pollution from solid biomass fuels and improve maternal and child health outcomes in low- and middle-income countries: A systematic review protocol. Syst. Rev. 2021, 10, 33. [CrossRef]

16. Quinn, A.K.; Bruce, N.; Puzzolo, E.; Dickinson, K.; Sturke, R.; Jack, D.W.; Mehta, S.; Shankar, A.; Sherr, K.; Rosenthal, J.P. An analysis of efforts to scale up clean household energy for cooking around the world. Energy Sustain. Dev. 2018, 46, 1-10. [CrossRef]

17. World Bank Clean and Improved Cooking in Sub-Saharan Africa: A Landscape Report Africa Renewable Energy Access Program (AFREA). Available online: https:/ / openknowledge.worldbank.org/handle/10986/22521 (accessed on 1 March 2021).

18. Wright, L.L.; Eaton, L.M.; Perlack, R.D.; Stokes, B.J. Woody biomass. In Comprehensive Renewable Energy; Elsevier: Boston, MA, USA, 2012; Volume 5, pp. 263-291, ISBN 9780080878737.

19. Simkovich, S.M.; Williams, K.N.; Pollard, S.; Dowdy, D.; Sinharoy, S.; Clasen, T.F.; Puzzolo, E.; Checkley, W. A systematic review to evaluate the association between clean cooking technologies and time use in low- and middle-income countries. Int. J. Environ. Res. Public Health 2019, 16, 2277. [CrossRef] [PubMed]

20. Goel, K.; Sarta, J.A.; Gagan, A.; Parul, G.; Vijay, K. A cross-sectional study on prevalence of acute respiratory infections ARI in under five children of Meerut District India. J. Community Med. Health Educ. 2013, 2, 1-9. [CrossRef]

21. Mondal, D.; Paul, P. Effects of indoor pollution on acute respiratory infections among under-five children in India: Evidence from a nationally representative population-based study. PLOS ONE 2020, 15, e0237611. [CrossRef]

22. Naz, L.; Ghimire, U. Assessing the prevalence trend of childhood pneumonia associated with indoor air pollution in Pakistan. Environ. Sci. Pollut. Res. 2020, 27, 44540-44551. [CrossRef]

23. Buchner, H.; Rehfuess, E.A. Cooking and season as risk factors for acute lower respiratory infections in African children: A cross-sectional multi-country analysis. PLoS ONE 2015, 10, e0128933. [CrossRef] [PubMed]

24. Tekle, A.G.; Worku, A.; Berhane, Y. Factors associated with acute respiratory infection in children under the age of 5 years: Evidence from the 2011 Ethiopia Demographic and Health Survey. Pediatr. Health Med. Ther. 2015, 6, 9. [CrossRef]

25. DHS. The DHS Program-DHS Methodology. Available online: https://dhsprogram.com/methodology/survey-types/DHSMethodology.cfm (accessed on 30 June 2021). 
26. The Demographic and Health Surveys. The DHS Program-Available Datasets. Available online: https://dhsprogram.com/ data/available-datasets.cfm (accessed on 28 February 2021).

27. The Demographic and Health Surveys. The DHS Program: Protecting the Privacy of DHS Survey Respondents. Available online: https:/ / dhsprogram.com/What-We-Do/Protecting-the-Privacy-of-DHS-Survey-Respondents.cfm (accessed on 5 March 2020).

28. World Health Organization. WHOI RSV Surveillance Case Definitions. Available online: https://www.who.int/teams/globalinfluenza-programme/global-respiratory-syncytial-virus-surveillance/case-definitions (accessed on 6 July 2021).

29. World Health Organization. Household Energy Use: DRAFT Catalogue of Cooking, Heating and Lighting Fuels and Technologies. Available online: https://mics.unicef.org/ files?job=W1siZiIsIjIwMTcvMDIvMDMvMTYvMjcvMjUvNTk5L1BpY3 RvcmlhbHNfV0hPX0hvdXNlaG9sZF9FbmVyZ3lfVXN1X0NhdGFsb2d1ZV9TZXB0ZW1iZXJfMjAxN18ucGRmIl1d\&sha=57b4 a452fcc0ac88 (accessed on 30 June 2021).

30. The Demographic and Health Surveys. The DHS Program-Research Topics-Wealth Index. Available online: https:// dhsprogram.com/topics/wealth-index/index.cfm (accessed on 1 March 2021).

31. R Core Team. R: A Language and Environment for Statistical Computing; R Core Team: Boston, MA, USA, 2020.

32. Fox, J.; Weisberg, S. An R Companion to Applied Regression, 3rd ed.; Sage: Thousand Oaks, CA, USA, 2019.

33. International Energy Agency; International Renewable Energy Agency; United Nations; World Bank Group; World Health Organization. Access to clean fuels and technologies for cooking. In Tracking SDG7: The Energy Progress Report 2018; World Bank: Washington, DC, USA, 2018; pp. 40-55.

34. Zhang, Y.; Li, Z. COVID-19's Impact on the Transition to clean Cooking Fuels: Initial Findings from a Case Study in Rural Kenya. Available online: https:/ / openknowledge.worldbank.org/handle/10986/35258 (accessed on 30 June 2021).

35. Shupler, M.; Mwitari, J.; Gohole, A.; Anderson de Cuevas, R.; Puzzolo, E.; Čukić, I.; Nix, E.; Pope, D. COVID-19 impacts on household energy \& food security in a Kenyan informal settlement: The need for integrated approaches to the SDGs. Renew. Sustain. Energy Rev. 2021, 144, 111018. [CrossRef]

36. Von Schirnding, Y.; Bruce, N.; Smith, K.; Ballard-Tremeer, G.; Ezzati, M.; Lvovsky, K. Addressing the Impact of Household Energy and Indoor Air Pollution on the Health of the Poor: Implications for Policy Action; WHO: Geneva, Switzerland, 2002.

37. Khalequzzaman, M.; Kamijima, M.; Sakai, K.; Ebara, T.; Hoque, B.A.; Nakajima, T. Indoor air pollution and health of children in biomass fuel-using households of Bangladesh: Comparison between urban and rural areas. Environ. Health Prev. Med. 2011, 16, 375-383. [CrossRef] [PubMed]

38. Wiedinmyer, C.; Dickinson, K.; Piedrahita, R.; Kanyomse, E.; Coffey, E.; Hannigan, M.; Alirigia, R.; Oduro, A. Rural-urban differences in cooking practices and exposures in Northern Ghana. Environ. Res. Lett. 2017, 12, 065009. [CrossRef]

39. Barnes, B.; Mathee, A.; Moiloa, K. Assessing child time-Activity patterns in relation to indoor cooking fires in developing countries: A methodological comparison. Int. J. Hyg. Environ. Health 2005, 208, 219-225. [CrossRef]

40. Ezzati, M.; Kammen, D.M. Indoor air pollution from biomass combustion and acute respiratory infections in Kenya: An exposure-response study. Lancet 2001, 358, 619-624. [CrossRef]

41. Pope, D.; Bruce, N.; Dherani, M.; Jagoe, K.; Rehfuess, E. Real-life effectiveness of 'improved' stoves and clean fuels in reducing PM2.5 and CO: Systematic review and meta-analysis. Environ. Int. 2017, 101, 7-18. [CrossRef]

42. Weaver, A.M.; Gurley, E.S.; Crabtree-Ide, C.; Salje, H.; Yoo, E.H.; Mu, L.; Akter, N.; Ram, P.K. Air pollution dispersion from biomass stoves to neighboring homes in Mirpur, Dhaka, Bangladesh. BMC Public Health 2019, 19, 1-12. [CrossRef]

43. Smith, K.R.; Pillarisetti, A. Household air pollution from solid cookfuels and its effects on health. In Disease Control Priorities: Injury Prevention and Environmental Health, 3rd ed.; The World Bank: Washington, DC, USA, 2017; Volume 7, pp. 133-152, ISBN 9781464805226.

44. Taylor, E.T.; Nakai, S. Prevalence of acute respiratory infections in women and children in western sierra leone due to smoke from wood and charcoal stoves. Int. J. Environ. Res. Public Health 2012, 9, 2252-2265. [CrossRef]

45. Mishra, V.; Smith, K.R.; Retherford, R.D. Effects of cooking smoke and environmental tobacco smoke on acute respiratory infections in young Indian children. Popul. Environ. 2005, 26, 375-396. [CrossRef]

46. Alemayehu, M.; Alemu, K.; Sharma, H.R.; Gizaw, Z.; Shibru, A. Household fuel use and acute respiratory infections in children under five years of age in Gondar city of Ethiopia. J. Environ. Earth Sci. 2014, 4, 77-85.

47. Mishra, V. Indoor air pollution from biomass combustion and acute respiratory illness in preschool age children in Zimbabwe. Int. J. Epidemiol. 2003, 32, 847-853. [CrossRef]

48. Enyew, H.D.; Mereta, S.T.; Hailu, A.B. Biomass fuel use and acute respiratory infection among children younger than 5 years in Ethiopia: A systematic review and meta-analysis. Public Health 2021, 193, 29-40. [CrossRef] [PubMed]

49. Dherani, M.; Pope, D.; Mascarenhas, M.; Smith, K.R.; Weber, M.; Bruce, N. Indoor air pollution from unprocessed solid fuel use and pneumonia risk in children aged under five years: A systematic review and meta-analysis. Bull. World Health Organ. 2008, 86, 390-394. [CrossRef] [PubMed]

50. Odo, D.B.; Yang, I.A.; Knibbs, L.D. A systematic review and appraisal of epidemiological studies on household fuel use and its health effects using demographic and health surveys. Int. J. Environ. Res. Public Health 2021, 18, 1411. [CrossRef] [PubMed]

51. Alam, A.; Tawale, N.; Patel, A.; Dibley, M.J.; Jadhao, S.; Raynes-Greenow, C. Household air pollution intervention implications: Findings from qualitative studies and a field trial of clean cookstoves in two rural villages in India. Int. J. Environ. Res. Public Health 2016, 13, 893. [CrossRef] [PubMed] 
52. Havens, D.; Wang, D.; Grigg, J.; Gordon, S.B.; Balmes, J.; Mortimer, K. The cooking and pneumonia study (CAPS) in Malawi: A cross-sectional assessment of carbon monoxide exposure and carboxyhemoglobin levels in children under 5 years old. Int. J. Environ. Res. Public Health 2018, 15, 1936. [CrossRef]

53. Gordon, S.B.; Bruce, N.G.; Grigg, J.; Hibberd, P.L.; Kurmi, O.P.; Lam, K. bong H.; Mortimer, K.; Asante, K.P.; Balakrishnan, K.; Balmes, J.; et al. Respiratory risks from household air pollution in low and middle income countries. Lancet Respir. Med. 2014, 2, 823-860. [CrossRef]

54. Arnold, F.; Khan, S.M. Perspectives and implications of the Improving Coverage Measurement Core Group's validation studies for household surveys. J. Glob. Health 2018, 8, 010606. [CrossRef]

55. Croft, N.T.; Marshall, A.M.J.; Allen, C.K. Guide to DHS Statistics (Version 2); ICF International: Rockville, MD, USA, 2018. 